\title{
Role of Ceratophyllum demersum in recycling macro elements from wastewater
}

\author{
MARYAM FOROUGHI * \\ Young Researchers Club, Khorasgan Branch, Islamic Azad University, Isfahan, Iran; Foroughi.maryam@yahoo.com
}

\begin{abstract}
Water is one of the most stable and abundant complexes on nature that can be polluted with natural and human factors. Therefore, it is necessary to ensure a timely warning for possible accumulation of polluting metal in natural waters in order to protect public health. One of the economic and rapid methods for elements removal is displacement of metals by biosorption. The purpose of this study is to investigate how much Ceratophyllum demersum (C. demersum) enables to remove elements from aquatic environments. Three treatments in four replications for purifying wastewater by $C$. demersum were designed. The treatments included raw municipal wastewater (RMW) and treated municipal wastewater (TMW) and diluted compost latex (DCL). The experiment was performed at the open air of Khorasgan University area for 18 days without aeration. After this examination, the accumulation of Magnesium in C. demersum indicated that the Magnesium in TMW, RMW and DCL were increased $96.29 \%, 100 \%$ and $73.52 \%$ respectively. These results demonstrate that in all of the treatments $C$. demersum could absorb high Magnesium concentration from the aquatic environment. In addition, this investigation demonstrated that the amount of Calcium, Nitrogen, Phosphorous, Sodium and Potassium accumulated in $C$. demersum absorbed efficiently from the aquatic environments respectively. Therefore, it was concluded that $C$. demersum could be used to refine polluting metal from wastewater and could be the best biosorption method for protecting the water pollution in the environment. @JASEM
\end{abstract}

Key words: Ceratophyllum demersum, biosorption, RMW, TMW, DCL, aquatic environments.

\begin{abstract}
An important dimension of water resources that has not received due attention is its quality aspects. The rapid industrialization in developing countries, though contributed to economic development, has resulted in heavy losses to economic welfare in terms of effects on agricultural activities, human health and ecosystem at large through air and water pollution.
\end{abstract}

Basically, water pollution poses a serious challenge due to its impact on a large number of economic activities. The problem of water pollution acquires greater relevance in the context of an agrarian economy. While the magnitude of the problem is limited and widely spread, the losses due to its impact are quite substantial. This is mainly due to its direct impact on human health and livelihoods (Reddy, 2006). Therefore, it is necessary to ensure a timely warning for possible accumulation of polluting metal in natural waters in order to protect public health (fang, 1995; SanzMedel, 1999). The traditional methods for the removal of heavy metals from water are generally expensive or inadequate to treat highly dilute solutions (Volesky, 2003).
The problems of aquatic pollution are likely to exacerbate and pose significant ecological/public health risk in the coming years, especially in developing countries (Islam and Tanka, 2004). Recently, particular attention was paid to metal ions binding by non-living (biosorption) and living biomass (bioaccumulation). The majority of studies usually focus on bioremoval of metals from wastewater (Pagnanelli et al., 2001; Naja and Volesky, 2006; Miretzky et al., 2006; Keskinkan et al., 2004).

Submerged aquatic vascular plants are known to absorb nutrients, such as nitrogen $(\mathrm{N})$ and phosphorus (P), far in excess of their normal metabolic requirements (Wilson, 1972). Thus, considerable amounts of nutrients can be stored in plant dominated littoral areas of aquatic ecosystems. Nutrient uptake and storage by aquatic plants is an integral part of the biogeochemical cycle of both natural wetland ecosystems (Mitsch and Gosselink, 2000) and treatment wetlands (Kadlec and Knight, 1996; Reed et al., 1995). Because some species of 
submerged aquatic vegetation (SAV) assimilate nutrients directly from the water column, this community may play an important role in maximizing nutrient removal in treatment wetlands (Gumbricht, 1993).

Ceratophyllum demersum grows in shallow, muddy, quiescent water bodies at lowlight intensities. It is a submerged, rootless, free floating, perennial and it is cosmopolitan in distribution. This submerged macrophyte has a high capacity for vegetative propagation and biomass production even under low nutritional conditions, which removes excess nutrients and cadmium from stagnant waters (Best, 1977; Pomogyi et al., 1984). It is useful as an oxygenate or for use in the closed equilibrated biological aquatic system (CEBAS) (Ornes and Sajwan, 1993; Aravind and Prasad, 2005).

The purpose of our study was to evaluate the role of Ceratophyllum demersum in removing macro elements from wastewater and to establish the role of this plant in improving water quality.

\section{MATERIALS AND METHODS}

The aquatic plant (Ceratophyllum demersum) was collected from Zayanderood river in spring season of 2009 (Isfahan, Iran). Samples were thoroughly washed with tap water to remove any soil/sediment particles attached to the plant surfaces.

One hundred grams of ceratopyllum demersum were then placed in urban wastewater, Khorasgan University's sewage water and diluted compost latex in each 12 bottles (volume 6 Lit). The weather of Khorasgan University during this study was between 28 and 32 degree centigrade. However, the temperature of wastewater, which plants were located in them, was between 24 and 26 degree centigrade. The experiment was performed at the open air of Khorasgan University area under natural daylight for 18 days without aeration. Ceratopyllum demersum had been harvested from each treatment after 18 days. Then, macro elements such as $\mathrm{N}, \mathrm{P}, \mathrm{Ca}, \mathrm{Mg}, \mathrm{Na}$ and $\mathrm{K}$ was measured and compared with original plant which was not linked with treatments.

Harvested plants were thoroughly washed in distilled water and oven dried at 80 Centigrade. Dried plant material was powdered and wet digested in HNO3:HClO4 (3:1, v/v) at 70 Centigrade. Total Nitrogen (TN) was determined by the Kjeldahl digestion, distillation, and titration method (Nelson and Sommers, 1973), Phosphorous (P) was determined according to the estimation of available phosphorous (Olsen et al., 1954). Sodium and potassium was measured by flame photometer, Calcium and magnesium in aquatic plant were measured by titration method with EDTA (Richards and Abate, 1995).

All of the data collected during this experiment were analyzed with Statistical Package for the Social Sciences (SPSS) software (version 16.0) and were compared with the Duncan's multiple range tests.

\section{RESULT AND DISCUSSION}

Nitrogen concentration in plants: The concentrations of Nitrogen in sample of plant in TMW, RMW and DCL treatments increased $44.77 \%, 22.72 \%$ and $34.09 \%$ respectively after 18 days (figure 1 ).

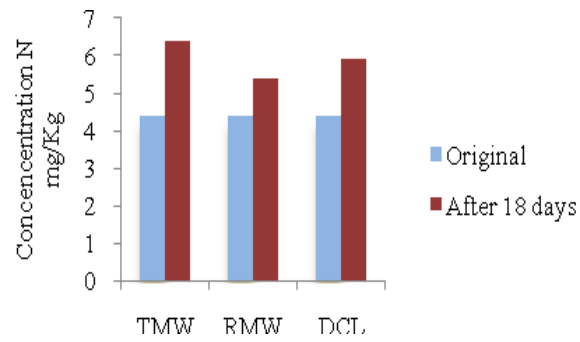

Figur1. Concentration of nitrogen in plants 
Nitrate is not stable as it is readily absorbed by plants and microorganisms and immobilized as part of their protein (Patterson, 2003). Unrooted submerged vegetation such as $C$. demersum requires nutrient uptake from the water (Mjelde and Faafeng, 1997).

Phosphorous concentration in plants: The concentration of Phosphorous (P) that accumulated in Ceratophyllum demersum was shown in figure 2 . The concentration of $P$ in sample of TMW, RMW and DCL treatments increased $63.67 \%, 16.77 \%$ and $5.4 \%$ respectively after 18 days, then result showed that Ceratophyllum demersum could adsorb high concentration of $\mathrm{P}$ from wastewater. Submerged macrophytes could be used in reducing the $\mathrm{P}$ levels of nutrient enriched waters (Gao et al., 2009). Mjelde and Faafeng (1997) showed C. demersum development in shallow Lakes with high phosphorous load. Submerged macrophytes can reduce the concentration of different $\mathrm{P}$ species in the overlying water, mainly by uptaking the $\mathrm{P}$ from overlying water. However, aquatic vegetation, particularly submerged macrophytes, has declined and even disappeared from many lakes as a result of artificial eutrophication and irrational fishery management (Tong et al., 2004).

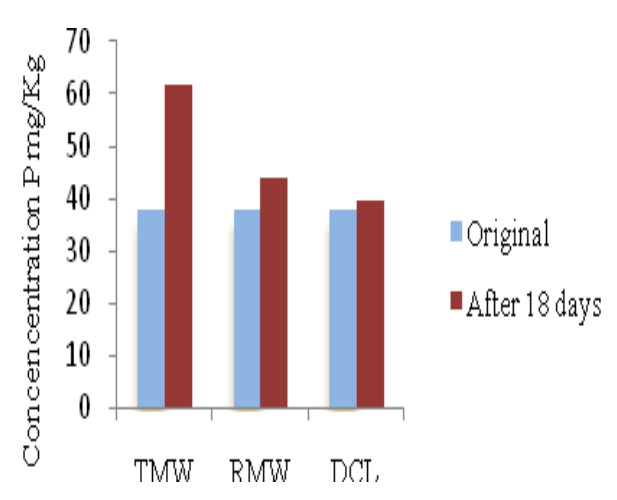

Fig2. Concentration of Phosphorous in plants

Calcium concentration in plants: Analysis of Calcium $(\mathrm{Ca})$ in samples showed that concentration of $\mathrm{Ca}$ in all plants of TMW, RMW and DCL increased $87.61 \%, 60.03 \%$ and $27.95 \%$ respectively after 18 days (figure 3).

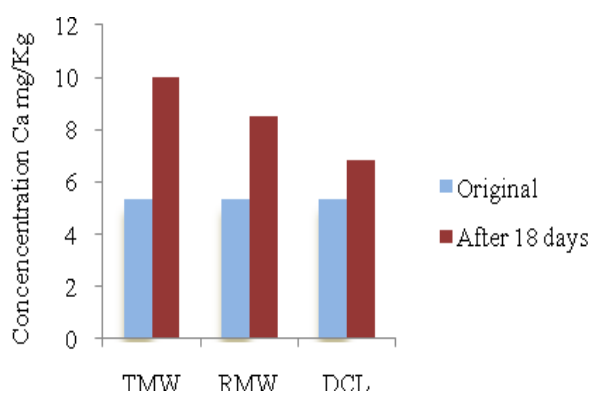

Figur3. Concentration of Calcium in plants

Mishra et al., (2008) showed that aquatic plants could accumulate higher concentration of nutrient. When they covered aquatic plants with coal mining, concentration of $\mathrm{Ca}$ increased $38.8 \pm 3.8$ percent in tissue of plants. Aquatic plants could be reduced $68.6 \%$ hardness of wastewater (Tripathi et al., 1991).

Magnesium concentration in plants: Results of Magnesium $(\mathrm{Mg})$ in this study indicated that the $\mathrm{Mg}$ concentration in Ceratophyllum demersum increased $96.29 \%, 100 \%$ and $73.52 \%$ respectively in TMW, RMW and DCL after 18 days (figure 4).

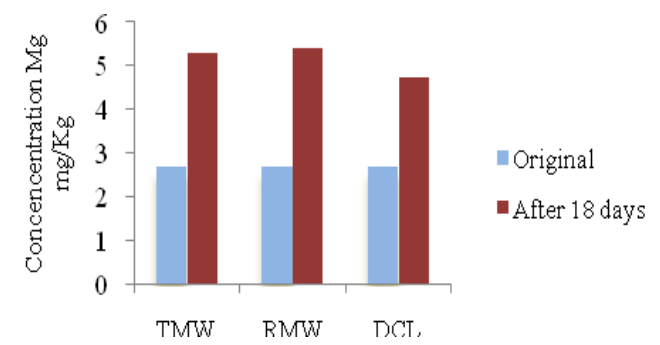

Figur4. Concentration of Magnesium in plants

Mishra et al. (2008) showed that concentration of Magnesium in E. crassipes increased $77.77 \%$ after put in mining wastewater. 
Na concentration in plants: The amount of Sodium (Na) that was removed by C.demersum was $2.78 \%$ from DCL and $19.3 \%$ from TMW and RMW (figure 5).

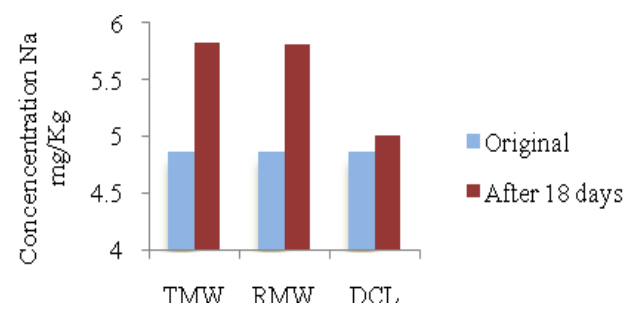

Tripa

Figur5. Concentration of Sodium in plants

aquatic plants in laboratory conditions to evaluate their potential role in wastewater treatment. Their result showed that these aquatic plants could reduce total $74.6 \%$ from alkalinity of wastewater.

Potassium concentration in plant: The concentrations of Potassium $(\mathrm{K})$ in sample of Ceratophyllum demersum in TMW, RMW and DCL treatments raised $9.00 \%$, $4.02 \%$ and $7.28 \%$ respectively after 18 days (figure 6).

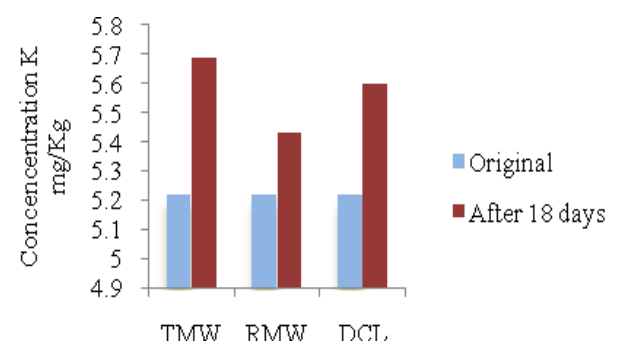

Figur6. Concentration of Potassium in plants

Some others aquatic plants same $E$. crassipes could adsorb $28 \% \mathrm{~K}$ from mining wastewater and concentration of $\mathrm{K}$ raised $10 \%$ in tissue of $L$. minor when this covered with wastewater (mishra et al., 2008).

Conclusion: From the work presented here, the aquatic submerged plant ceratopyllum demersum can be effective as a biosorbent for the removal of Nitrogen, phosphorus, calcium, magnesium, sodium and potassium from wastewater. This study showed that $C$. demersum could be as a major role in the environmental conditions of stagnant and flowing waters and this plant could adsorb elements and decrease pollution of wastewater.

\section{REFERENCE}

Aravind, P; Prasad, MNV (2005). Modulation of cadmium induced oxidative stress in Ceratophyllum demersum by zinc involves ascorbate-glutathione cycle and glutathione metabolism. Plant Physiol. Biochem. 43: 107-116.

Best, EPH (1977). Seasonal changes in mineral and organic components of Ceratophyllum demersum and Elodea canadiensis. Aquat. Bot. 3: 337-348.

Fang, ZL (1995). Flow Injection Atomic Absorption Spectrometry, Chichester, Wiley.

Gao, J; Xiong, ZH; Zhang, J; Zhang, W; Obono, $\mathrm{MbaF}$ (2009). Phosphorous removal from water of eutrophic Lake Donghu by five submerged macrophytes, De salination 242: 193-204.

Gumbricht, T (1993). Nutrient removal process in freshwater submersed macrophyte systems. Ecol. Eng. 2: 1-30.

Islam, MdSh; Tanaka, M (2004). Impacts of pollution on coastal and marine ecosystems including coastal and marine fisheries and approach for management: a review and synthesis, Mar. Pollut. Bull. 48: 624-649.

Kadlec, RH; Knight, RL (1996). Treatment Wetlands. Lewis Publishers, Boca Raton, FL.

Keskinkan, O; Goksu, MZL; Basibuyuk, M; Forster, CF (2004). Heavy metal adsorption properties of a submerged aquatic plant (Ceratophyllum demersum). Bioresour. Technol. 92: 197-200.

Mjelde, M; Faafeng, BA (1997). Ceratophyllum demersum Hampers phytoplankton development in some small Norwe Gian lakes over awide range of phosphorus concentrations and Geographic allatitude. Fresh Water Biol. 37: 355-365.

Miretzky, P; Saralegui, A; Fernandez Cirelli, A (2006). Simultaneous heavy metal removal mechanism by dead macrophytes. Chemosphere, 62: 247-254. 
Role of Ceratophyllum demersum.....

Mishra, VK; Upadhyaya, AR; Pandey, SK; Tripathi, BD (2008). Heavy metal pollution induced due to coal mining effluent on surrounding aquatic ecosystem and its management through naturally occurring aquatic macrophytes, Bioresource Technology, 99: 930-936.

Mitsch, WJ; Gosselink, JE (2000). Wetlands, 3rd ed. John Wiley \&Sons, Inc., New York, NY.

Naja, G; Volesky, B (2006). Multi-metal biosorption in a Wxed bed Xowthrough column. Colloid Surf. A 281: 194-201.

Nelson, DW; Sommers, LE (1973). Determination of total nitrogen in plant material. Agron. J.65:109-112.

Olsen, SR; Cole, CV; Watanabe, FS; Dean, LA (1954). Estimation of ailable phosphorus in soils by extraction with sodium bicarbonate. USDA Circular 939. U.S. Government Printing Office, Washington D.C.

Ornes, WH; Sajwan, KS (1993). Cadmium accumulation And bioavailability in coontail (Ceratophyllumdemersum) plants. Water Air Soil Pollut. 69: 291-300.

Pagnanelli, F; Trifoni, M; Beolchini, F; Esposito, A; Toro, L; Veglio, F (2001). Equilibrium biosorption studies in single and multi-metal systems. Process Biochem. 37: 115-124.

Patterson, RA (2003). Nitrogen in Wastewater and its Role in Constraining On Site Planning in Future Directions for On site Systems: Best Management Practice. Proceedings of On-site '03 Conference by

Patterson, R.A. and Jones, M.J. (Eds). Held at University of New England, Armidale 30th
September to 2nd October 2003. Published by Lanfax Laboratories Armidale. ISBN 0-9579438-1-4 pp 313320

Pomogyi, P; Best, EPH; Dassen, JHA; Boon, JJ (1984). On the relation between age, plant composition and nutrient release from living and killed Ceratophyllum plants. Aquat. Bot. 19: 243250 .

Reddy, V R; Behera, B (2006). Impact of water pollution on rural communities: An economic analysis, Ecological Economics 58, 520- 537.

Reed, SC; Crites, RD; Middle brooks, EJ (1995). Natural Systems for Waste Management and Treatment, 2nd ed. McGraw Hill, Inc., New York, NY.

Sanz-Medel, A (1999). Flow Analysis with Atomic Spectrometric Detectors, Amsterdam, Elsevier.

Tripathi, BD; Shukla, SC (1991). Biological treatment of wastewater by selected aquatic plants, Environmental Pollution, Volume 69, Issue 1, pp: 6978.

Tong, CH; Yang, XE; Pu, PM (2004). Purification of eutrophicated water by aquatic plant, Chinese J. Appl. Ecol., 15: 1447-1450.

Volesky, B (2003). Sorption and Biosorption, BVSorbex, Inc., St. Lambert, Quebec.

Wilson, D (1972). Phosphate nutrition of the aquatic angiosperm, Myriophyllum exalbescens Fern. Limnol. Oce-anogr. 17: 612-616. 